\title{
Early Censorship in Paris: A New Look it the Roles of the Parlement of Paris nd of King Francis I
}

AMES K. FARGE

"ears about the spread of ideas deemed dangerous or false remain deep ithin the consciousness of even our post-Enlightenment world. Not urprisingly then, social groups in earlier centuries habitually tried to uppress such ideas to promote order in this world and to secure salvation n the next. Then, as now, most people differed not so much on whether to ensor as on what to censor.

Few objected when the advent of printing from movable type prompted spate of new legislation to stop the rapid spread of errors made possible y the printed book. First popes, then princes and magistrates, drafted laws alling either for the submission of manuscripts prior to printing or for the lestruction of offensive books already produced. Secular authorities sought irst to control political tracts, but they readily supported the clergy in uppressing books declared heterodox. By the end of the sixteenth century, atalogues of prohibited books had appeared in over a dozen major centres liroughout Europe, and the Index librorum prohibitorum established in the a of Trent in 1559 continued to censor books until its abolition during he Second Vatican Council in $1966 .{ }^{1}$ The controversy over censorship ontinues recurrently at all levels of government and social groups.

Franz Reusch's pioneering study in the nineteenth century of the early ensorship of printed books ${ }^{2}$ was far too vast a project for the restricted cale he employed. Only recently has the subject engaged the efforts of an ditor who has mustered the scholarly and financial resources equal to the ask. The "Index des Livres Interdits" series under the direction of J.-M. De Bujanda at the Centre d'Études de la Renaissance in the Université de 
post-Gutenberg era. ${ }^{3}$

Five years ago, as I prepared the "Introduction historique" to the Paris volume of that series, ${ }^{4}$ some contention arose about the stress I placed on the collaboration between the Parlement of Paris and the Faculty of Theology of the University of Paris in censoring books. Today, relying on further research, I can only emphasize that cooperation even more strongly. At the same time, the new materials likewise require new evaluations, ${ }^{5}$ first, of the effects of the Parlement's censorship during the 1520s and, second, of the role of King Francis I in censorship during the second half of his reign. This is what I propose to do in the present article.

The censorship of books in Paris was essentially the work of three institutions: the University of Paris' Faculty of Theology, the Parlement of Paris and the King. ${ }^{6}$ From about 1521 until 1535 , however, the vigilance exercised by the Faculty and the court of Parlement was usually at cross-purposes to the intentions of King Francis I, who sought to protect the works of certain humanists and evangelical reformers. In 1523, for example, despite a series of injunctions issued by the Parlement against Martin Luther's books, Francis banned two anti-Lutheran books written by Jérôme de Hangest and by Lambertus Campester ${ }^{7}$ and forbade any action by the Parlement and the Faculty against Erasmus and Lefèvre d'Étaples. In 1526, he suppressed Noël Beda's disapproving Annotations on Erasmus' and Lefèvre's works and rescued Louis de Berquin, the translator and publicist of humanists and reformers, from prosecution by the Parlement. At the same time, Francis attempted to gain the University's approval of a book against Beda - probably the work of Berquin. ${ }^{8}$

The foundation for the close cooperation of the Parlement and the Faculty of Theology in censorship of humanists and reformers in opposition to the King was laid in 1516-1518 by their joint, vehement resistance to the King's Concordat with Pope Leo X. It is not surprising then that the two institutions continued to oppose the King in religious questions such as the orthodoxy of books and preaching. Their persistence often triumphed over the more tolerant policies of the King, whose relentless wars against the Emperor led to defeat, captivity and financial straits which weakened his liberal stances vis-à-vis the stringent demands of more conservative institutions like the Church, the Parlement and the University of Paris.

From 1535 until his death in 1547, however, Francis I rarely intervened in the censorship decreed by the Faculty and the Parlement, breaching this new policy only by his ultimately unsuccessful attempts to protect the 
printers Étienne Dolet, who was executed, and Robert Estienne, who fled to Geneva. Francis I's successor, Henry II (1547-1559), consummated a close, tri-partite collaboration between King, Faculty, and Parlement in these matters by issuing his Edict of Châteaubriant (1551), in which fourteen of the forty-six articles provided for the censorship of offensive books.

The Faculty of Theology's six catalogues of prohibited books appeared from 1544 to 1556 . The 1544 edition was the first printed Index of censured books to appear anywhere. Issued solely under the aegis of the Faculty of Theology, however, it lacked the coercive sanctions required to be effective. But the next five catalogues $(1545,1547,1549,1551$ and 1556) all appeared with the approval of both the Parlement and the monarchy, and threatened sanctions against anyone who printed, sold, read or possessed any of the forbidden books. The 1551 catalogue, especially important because it appeared in conjunction with the royal Edict of Châteaubriant, listed 396 titles and employed improved standards of bibliographical precision. The 1556 version raised the total of forbidden books to 526. While the Faculty of Theology continued to censor books during the subsequent period - it even scrutinized the first Roman Index of 1559 - its 1556 edition proved to be the final catalogue of censured books issued in Paris.

Within that brief framework we can now examine some of the materials that have recently come to light and explore their implications for our understanding of early censorship in Paris. First, we turn our attention to the three arrêts, or injunctions, issued in 1521 by the Parlement of Paris forbidding the printing of any book concerning religion without the prior consent of the Faculty of Theology. Two aspects of these injunctions had long remained problematic: first, the timing of the earliest injunction, which appeared four weeks prior to the Faculty's own condemnation of Luther; and second, the authorship of all three injunctions ascribed to King Francis I. The three arrêts seemed therefore to imply, first, that the initial censor of Luther in Paris was King Francis I himself and, second, that he continued to direct that policy at least throughout 1521 . Both assumptions, however, are mistaken. The first injunction, dated 18 March 1521 (n. st.), had nothing at all to do with either Luther or Francis I. It concerned a completely orthodox work, a commentary on the Quodlibets of Duns Scotus, ${ }^{9}$ which the University's rector brought before the court of Parlement solely because its title-page falsely vaunted special approbation by the University. The extensive pleas argued in the case touched neither on Luther nor on any other alleged heretical ideas. As for the imputed royal authorship of this 
injunction - already called into question in the Index volume - it is now clear that, even though all three injunctions bore his name, King Francis I had no real part in them. The royal name appeared merely as a pro forma indication of concurrence in the decisions by the King's procurator general in the Parlement, Le Lièvre, and of the origin of the arrêts in the King's Parlement.

The real import of that first injunction, of course, extended far beyond the pique of the University at the unauthorized use of its name. The Parlement's decision to require the prior approval by the Faculty of Theology for the printing or selling of any book on theology or Sacred Scripture ${ }^{10}$ established clear precedent for several later injunctions against the dissemination and possession of the works of reformers and certain humanists. No one challenged the University's lawyer, Lautier, when he cited canon law (cap. 4, dist. 21) to confirm the University's authority per modum disputationis to judge "whether propositions are good or evil, heretical or catholic."11

The second "royal" injunction, dated 1 August 1521, condemned two books, the spurious Determinatio secunda almae facultatis Parisiensis ${ }^{12}$ and the so-called Aytanea Germanorum. ${ }^{13}$ The bailiff of the Parlement testified to his public proclamation of the arrêt and adds that "from now on nobody can pretend ignorance in this matter." 14 The third arrêt of 1521 (dated 4 November), previously known only in its Latin translation ${ }^{15}$, has now come to light in its contemporary French version. ${ }^{16}$ Citing Konrad Resch's bookshop, the Écu de Bâle, as a principal offender in the dissemination of dangerous books, it thus raises the question whether Resch was one of the unnamed booksellers who were imprisoned in that same year 1521 for selling a forbidden book. ${ }^{17}$ Once again the bailiff attests to his public proclamation of the arrêt and assures the court of Parlement that "cy apres aucun n'en puisse pretendre cause d'ignorance." 18 Still another newly found document is the 3 May 1522 official request from the Faculty of Theology asking the Parlement to apply its decrees of censorship to Lyon and to all the other cities and jurisdictions of the kingdom. ${ }^{19}$ The Parlement's ready agreement to this request is only one of many such indications of the working relationship of the two institutions.

The Parlement's vigilance about books appears regularly in cases during the 1520s. Previously unknown documentation about two cases of censorship, one famous and the other unfamiliar, will serve to illustrate this vigilance. The unfamiliar case concerns a certain Dominican friar, Girard 
(alternatively called "Bernard") Hecquefort, a native of Nijmegen, who arrived in Paris in June 1525 from England via Cambrai and was said to have brought with him about 100 écus worth of heretical books to sell. He was immediately put under guard at Sainte-Geneviève Abbey to be questioned by four members of the Parlement and two doctors of theology. His books - the titles, alas, are not specified - were of special interest to Pierre Lizet, the avocat du roi and later premier président of the Parlement. ${ }^{20}$

The famous case is the six-year-long suit brought by the Faculty of Theology against Jacques Merlin's Apologia for Origen. ${ }^{21}$ The abundant documentation in this litigation confirms the mutual confidence of Parlement and Faculty, and reveals the attitudes of both towards theologians who dissented from received tradition. In the words of the Faculty's lawyer, Jean Bochard, their "curiosity... is a species of pride and, on many occasions, a deadly sin when it leads one to deny as unknown what we hold as known. And as to such curiosity, it brings us uselessly to introduce division and schism into the Church..." Although Bochard was pleading on behalf of his client, the Faculty of Theology, the Parlement concurred fully with the Faculty's reasons and ruled against Merlin. The avocat du roi Pierre Lizet stressed in his summation that the case could set

a scandalous and dangerous precedent by casting doubt on the judgments and determinations of the Faculty, which is so essential to abolishing the damnable and foolish opinions which have proliferated recently against the determinations and doctrines of the Catholic Church.

He added that it was incumbent upon the Parlement to assure that

the authority and judgment of the Faculty of theology, whici: has always carried such a weighty and great reputation, be safeguarded and upheld, especially by its own members and alumni; for if these latter were permitted to impugn and challenge the judgments of their mother the Faculty, this would open up the occasion to others to hold it in contempt and to discount its rulings. ${ }^{22}$

In short, no one reading the Parlement's registers for the 1520 s would posit the existence of even a significant minority of so-called "liberal," reformist members who might have defended an Erasmus, a Lefèvre or a Luther. François Deloynes was dead by mid-1524; Louis Ruzć had already moved from the Parlement to the Châtelet; and Guillaume Budé, now a maitre des requêtes de l'Hôtel, scldom appeared in the court of Parlement. The premier président, Jean de Sclve (d. 1529), sometimes thought to have 
favoured the reform movement because several humanists dedicated books to him, was entirely traditionalist in matters of religion, as were such prominent members as the president Charles Guillard, André Verjus and Nicolas Brachet. Thus no discernible dissent occurred within the Parlement to its 1526 judgment against all new versions and vernacular translations of the Bible. ${ }^{23}$ On the contrary, neither that document nor the Parlement's obstinate opposition to royal orders for the release of Louis de Berquin leave any room to conclude that it concurred with the King's suppression of Noël Beda's Annotations against Lefèvre and Erasmus - even though it did prudently obey his orders. ${ }^{24}$ And, if Francis I really did intend after the famous lit de justice of 1527 to curtail the Parlement's jurisdiction in matters of religion - and there is little firm evidence that he did - the Parlement continued nonetheless to rule and to act independently in such matters. On 13 January 1528 , for example, it was trying to identify the printer of posters circulating in Meaux that claimed that "the new pope in Rome" had ordered everyone "to read, to re-read and to have others read the books of Luther." 25 In 1529, it was again the Parlement that dealt the ultimate censure possible to an author by sentencing Louis de Berquin to death. Elsewhere I have documented the joint inspections of Paris bookshops requested by the Faculty and approved by the Parlement in 1531 and $1532 .{ }^{26}$ And, although the censure in 1533 of the Miroir de l'âme pécheresse, a devotional book by the King's sister Marguerite, caused considerable trouble for the Faculty of Theology, the printer of that work, Antoine Augereau, did not long survive the affaire des placards a year later. Thus the joint surveillance of presses and bookshops continued into the 1530s.

A second category of new evidence about carly censorship concerns the results of the Parlement's juridical pursuit of printers and booksellers during the 1520s. These results are often thought to have been negligible. But we have already taken notice above of the Parlement's accusations against Konrad Resch in 1521 and of its search for the anonymous printer of the posters in 1528. In addition, even though none of the 1521 injunctions threatened non-conforming printers with imprisonment - punishment was set at a fine of 500 livres and possible exile from France - the University's Rector, Claude Le Maistre, reported in late 1521 that some booksellers - he uses the plural - had been put in prison by the Parlement for selling a forbidden book. ${ }^{27}$ This action coincided with the accusations against Konrad Resch. Two years later, at the express request of the Faculty of Theology, the Parlement sent its bailiff to interrogate the printer Simon de 
Colines and ordered him to appear in court for having printed Lefèvre d'Étaples' Commentarii initiatorii in quatuor evangelia. ${ }^{28}$ In 1525 , the University ruled that Jean Petit, who was probably the most prolific and prominent publisher in Paris, had acted in a manner prejudicial to the University and to his oath as a libraire juré by printing condemned books. ${ }^{29}$ The exact outcome of these confrontations with Resch, Colines and Petit is not known. On the one hand, we know that all three continued to exercise their trade in Paris. Resch in particular published works of Erasmus and other authors held suspect by the Faculty of Theology. On the other hand, he forsook Paris definitively in 1526, and we know that another unidentified bookseller was indeed imprisoned in 1528, apparently through the efforts of Noël Beda, syndic of the Faculty. ${ }^{30}$ All six of these incidents from 1521 to 1528 antedate any previously known case of judicial action following censorship and should thus alter somewhat our previous impressions about the lack of particular effects of censorship during its first decade in Paris. The six cases certainly help to explain why the printer Pierre Vidoue would openly publish under his own name the anti-Erasmian works of Pierre Cousturier (Sutor), a doctor of the Faculty of Theology, but choose to print anonymously both the Litaneia Germanorum ${ }^{31}$ and the anti-Faculty satire Misocacus, dialogi tres, indicating the place of publication of the latter as "Utopia.,"32 They likewise help us better understand why, already in 1523, Lefèvre d'Étaples had begun to base his biblical translations exclusively on the Vulgate; why, from 1524, he suppressed all references to Erasmus; ${ }^{33}$ and why, in 1530, his French translation of the Bible appeared in Antwerp, not in France. Finally, let us also recall that from 1526 to 1565 no Paris printer published any new French translation of the Bible. Such facts and trends reveal that the real, perceived danger for offending authors, printers and booksellers, even in those earliest years, was more serious than we have previously surmised.

The third area inviting fresh interpretation involves King Francis I himself. We are accustomed to hear about this tolerant king who vaunted his liberal attitude towards new ideas by protecting humanists and reformers. We are told that in a mere passing fit of anger about the placards of 1534 he decided to suspend all printing in Paris, but then returned to his normal liberal policies. This picture needs reappraisal. We now know that Francis' original letters patent of 13 January 1535 (n. st.), which remains unrecovered, did not merely suspend but completely suppressed all printing in France. Let us examine part of that letter cited in the revised letters patent 
issued on 23 February 1535 (n. st.): “... no one, under pain of death by hanging, is hereafter to print or have printed in our kingdom any book."34 This important document has never been adequately analyzed. Even in this later revision, composed nearly six weeks after his so-called brief fit of anger - a fit that he somehow postponed until nearly three months after the incident provoking it, the posting of the placards - Francis I still clearly intended to limit the production of books to those he personally approved. He ordered the Parlement to designate twenty-four printers, from whom he would choose twelve, "who alone and no others will print in our city of Paris and not elsewhere books which are approved and necessary for the public good, without printing any new composition, under pain of being punished by the appropriate sentence as transgressors of our ordinances." He adds that no one is to print anything at all until the new arrangements have been completed, with violators to suffer death by hanging. ${ }^{35}$ If this was a minor lapse in the tolerant policy of a liberal prince, then we must begin to redefine "tolerant," "liberal," and "minor."

Indeed, the King himself, acting alone, provoked the most dramatic case of censorship in Paris in the late 1530s. This was the suppression in 1538 of the Cymbalum mundi, a satirical dialogue attributed to Bonaventure Des Périers, and the imprisonment of its printer Jean Morin. Many attempts have been made to explain and even to explain away the King's actions, but none of the latter take sufficient account of Francis's increasingly earnest worries about heterodoxy in his kingdom. While the last word has yet to be said on many aspects of this famous case, its immediate result was to set the stage for subsequent censorship by the Parlement and the Faculty. ${ }^{36}$ Further, a surprising number of additional royal initiatives against heresy in the early 1540 s, material rarely or never cited in the biographies of Francis or in monographs about the period, paved the way for promulgation of the more famous decrees of the Parlement against heretical books at that time.

In this light, the first printed catalogues of prohibited books in Paris in the early and mid-1540s can be seen much more clearly as the logical result of an established policy of censorship rather than as surprising or innovative actions. One might cite to the contrary the official complaint to the Parlement voiced by Paris booksellers against the 1545 catalogue. ${ }^{37}$ However, given the precedents of juridical pursuit and punishment of printers during the 1520 s and 1530 s, the numerous decrees and individual prohibitions of the previous three decades--especially of the early 1540 s - and a 
particularly intriguing series of inspections, inventories and personal interrogations carried out by the Parlement's bailiff at the shops of over sixty Paris booksellers in late $1542,{ }^{38}$ one can only surmise that their complaint did not challenge the Parlement's prerogative to censor or to impose sanctions - these matters were too well established. Rather they protested the application of these sanctions to the commerce in specific titles that they had continued to stock after the publication of the Faculty's innocuous 1544 catalogue.

The new evidence and interpretations offered here about the function of the Parlement of Paris in early censorship, about the effects of its sanctions imposed in the 1520s, and about the role of King Francis I as censor have nevertheless made clear that some aspects of early censorship in Paris still remain complex and some problems remain unsolved. Since, however, none of the new material offered here came to light in research specifically on censorship, we can plausibly expect that still more evidence about these problems may be accessible to those who will intentionally search for it. The most promising avenue for this may well be the Parlement's registers of criminal cases in the years 1520 to 1550 , a vast source that no one has methodically exploited on this subject for these decades. Until all the sources have been explored and all the unasked and unsolved questions about early censorship in Paris are addressed, we must admit that much is still hypothesis inviting further investigation into this strategic aspect of the Reformation and Counter-Reformation in France.

\section{Pontifical Institute of Mediaeval Studies}

\section{Notes}

Note: This article is a revised version of a paper presented on 30 October 1987 to the Sixteenth Century Studies Conference, meeting at Arizona State University, Tempe.

1 See Congregation for the Defence of the Faith, "Post litteras apostolicas," in Acta apostolicae sedis, 58 (1966): 445.

2 Franz Heinrich Reusch, Der Index der verbotenen Bücher. Ein Beitrag zur Kirchen-undLiteraturgeschichte, 2 vols.-in-3 (Bonn, 1883-1885; reprint Aalen, 1967). Idem, Die Indices librorum prohibitorum des sechzehnten Jahrhunderts (Tübingen, 1886; reprint Nieuwkoop, 1961).

3 J.-M. De Bujanda, ed. Index des livres interdits, projected 11 volumes (Sherbrooke: Centre d'Études de la Renaissance, 1984- ). Five volumes have appeared, 1984-1989, on the Paris, Louvain, Venice, Antwerp and Spanish Indexes.

4 See the "Introduction historique" in J.-M. De Bujanda, Francis M. Higman and James K. Farge, Index de l'Université de Paris, vol. 1 of the "Index des Livres Interdits" series, ed. by J.-M. De Bujanda (Sherbrooke, Québec: Centre d'Études de la Renaissance, 1985). 
5 Some of this material has recently been used in my article "L'Université et le Parlement: La censure à Paris au XVI ${ }^{\mathrm{e}}$ siècle," in Censure: De la Bible aux larmes d'Éros (Paris: Bibliothèque publique d'information, Centre Georges Pompidou, 1987), pp. 88-95; cf. also the "Anthologie," pp. 172-176.

6 Church officials like bishops and the Inquisitor usually worked through the Parlement and the University. The King worked either through one of his Conseils or through the Châtelet of Paris.

7 See James K. Farge, Orthodoxy and Reform in Early Reformation France: The Faculty of Theology of Paris, 1500-1543, Studies in Medieval and Reformation Thought, 32 (Leiden, 1985), p. 131.

8 Duodecim articuli infidelitatis Bedae (Paris: [Josse Bade], 1527).

9 The transcript of the case (Paris, Archives Nationales $X^{1 \mathrm{~A}} 4867, \rho^{\circ} 539 \mathrm{r}^{\circ}-541 \mathrm{v}^{\circ}$ ), calls the editor "François Bouquet, ministre général" of the Franciscans, and designates its Paris editor as a certain friar "Baptiste de Nullay." A certain "Guignon" printed 1250 copies of the book. This is certainly, however, the edition described by Brigitte Moreau, Inventaire chronologique des éditions parisiennes, (Paris, 1972- ), 2: no. 2398. The editor is really Francesco Licheto, the agent in Paris was Battista de Castiglione and the printer was Jean Granjon (with Jean II Du Pré and Hémon Le Fèvre).

10 A similar declaration had accompanied the condemnation of the works of the astrologer Simon de Phares in 1494. See Charles Du Plessis d'Argentré, Collectio judiciorum de novis erroribus (Paris, 1728-1736), 1, pt. 2: 324-331.

11 Paris, Archives Nationales, $X^{1 \mathrm{~A}} 4867$, fo $539 v^{\circ}$.

12 On this satirical piece, which some modern authors have mistakenly accepted as an authentic document produced by the Faculty, see the Index de l'Université de Paris, 1: 56, n. 71.

13 The Parlement and, apparently, its consultants at the University were confused by a somewhat clumsy rendering of the initial majuscule Greek letter lamda on the title-page of the 1521 Paris edition of Litancia Germanorum ([Paris: Pierre Vidoue], n.d.). See B. Moreau, Inventaire chronologique des éditions parisiennes $d u X V T^{\mathrm{e}}$ siècle, 3, (Paris, 1985), p. 89, no. 166. I am indebted to Mlle Brigitte Moreau for resolving this problem for me.

14 Paris, Archives Nationales $X^{1 \mathrm{~A}} 1523, \mathrm{l}^{\circ} 31 \mathrm{Or}^{\mathrm{O}}-\mathrm{v}^{\mathrm{O}}$; Paris, Bibliothèque Nationale MS Lat $12849, \mathrm{f}^{\circ} 17 \mathrm{Or}^{\circ}-\mathrm{v}^{\circ}$; MS Lat $12846, \mathrm{f}^{\circ} 397 \mathrm{r}^{\circ}$.

15 Charles Jourdain, Index chronologicus chartarum pertinentium ad historiam universitatis parisiensis (Paris, 1962), p. 327, \# MDXCVII.

16 Paris, Bibliothèque Nationale MS Lat $12849, \rho^{\circ} 169 \mathrm{r}^{\circ}$.

17 See below, p.178.

18 Paris, Bibliothèque Nationale MS Lat $16576, \mathrm{f}^{\circ} 26 \mathrm{r}^{\circ}-27 \mathrm{v}^{\circ}$.

19 Paris, Bibliothèque Nationale MS Lat $12849,1^{\circ} 171 \mathrm{r}^{\circ}$.

20 See, for example, Paris, Archives Nationales $X^{1 \mathrm{~A}} 1528, \rho^{\circ} 531 \mathrm{r}-533 \mathrm{v}^{\circ}$ (8 June 1525), $\mathrm{\rho}^{\circ} 538 \mathrm{v}^{\circ}$ (10 June 1525), $f^{\circ} 594 \mathrm{r}^{\circ}-v^{\circ}$ (5 July 1525). The conclusion of this case may lie in the records of the Criminal court of Parlement, a source I have not yet explored.

21 See, for example, Paris, Archives Nationales $X^{1 \mathrm{~A}} 8344, \mathrm{f}^{\circ} 12 \mathrm{v}^{\circ}-18 \mathrm{r}^{\circ}$.

22 Archives Nationales $X^{1 \mathrm{~A}} 8344, \Gamma^{\circ} 18 \mathrm{v}^{\circ}$.

23 Paris, Archives Nationales $X^{1 \mathrm{~A}} 1529, \mathrm{r}^{0} 107 \mathrm{r}^{\circ}-\mathrm{v}^{\circ}$ (5 February 1526 n. st.).

24 On this see James K. Farge, ed., Registre des procès-verbaux de la Faculté de théologie de l'Université de Paris, II (Paris, 1989), no. 161 B-C and notes 1526: 52-53.

25 Paris, Archives Nationales $\mathrm{X}^{1 \mathrm{~A}} 1531,1^{\circ} 8 \mathrm{Or}^{\circ}$ (13 January 1528 n.st.).

26 Index de l'Université de Paris, p. 61. 
27 See Paris, Bibliothèque Nationale, MS Lat $9951, \rho^{\circ} 36 \mathrm{v}^{\circ}$, which is the rector's summary report for the third quarter of 1521. The book was Philip Melanchthon's Adversus furiosum parisiensis theologastrorum decretum, a satire of the Faculty of Theology's Determinatio against Luther, which must not be confused with the spurious Determinatio secunda mentioned in note 2 above. No Paris editions of either book are known. This same matter, recorded in the deliberations of the English-German Nation, 1522-1552 (Archives de l'Université de Paris [Sorbonne], Registre 15), has recently been signalled by Astrik L. Gabriel, The University of Paris and its Hungarian Students and Masters during the Reign of Louis XII and François Ier (Notre Dame, IN. and Frankfurt-am-Main, 1986), p. 1 O3.

28 Paris, Bibliothèque Nationale, MS Lat $12849, \mathrm{f}^{\circ} 178 \mathrm{r}^{\circ}-\mathrm{v}^{\circ}$.

29 Archives de l'Université de Paris (Sorbonne), Registre 14, $\mathrm{f}^{\circ} 127 \mathrm{r}^{\circ}, 128 \mathrm{r}^{\circ}$ (6, 7 August 1524). The thesis of Agnès Masson-Maréchal, "L'université de Paris au début du XVI ${ }^{\mathrm{e}}$ siècle," École nationale des Chartes, Paris (1985), 3: 376, drew my attention to this incident.

30 Paris, Bibliothèque Nationale, MS Nouvelles acquisitions latines $1782, \mathrm{f}^{\circ} 218 \mathrm{v}^{\circ}$ (15 July 1528).

31 See above, note 13.

32 See Brigitte Moreau, Inventaire chronologique des éditions parisiennes, 3 (1521-1530) (Paris and Abbeville, 1985), no. 1063.

33 Pierre Aquilon, "Paris et la Bible française, 1516-1586," Censure: De la Bible aux larmes d'Éros (Paris, 1987), pp. 17-18.

34 Ordonnances des rois de France: Règne de François ${ }^{\mathrm{er}}$ (Paris, 1902- ), 7: 203-204, no. 686.

35 Paris, Archives Nationales $X^{1 \mathrm{~A}} 1538, \mathrm{f}^{\circ} 113 \mathrm{v}^{\circ}-114 \mathrm{r}^{\circ}$ (13 February $1535 \mathrm{n}$. st.). No wonder, then, that a Paris bookseller, when drawing up a post-mortem inventory of a recently deceased student, purposely omitted the title of Erasmus' De preparatione ad mortem "pour ce qu'il est suspect en la foy." See Roger Doucet, Les Bibliothèques de Paris (Paris, 1956), pp 36-37.

36 At this time, books from "Germany" - doubtless from Strasbourg and Basel, still the chief sources of objectionable books at this time - came under fire.

37 Published by Nathanaël Weiss, Bulletin de la Société de l'histoire du protestantisme français, 40 (1891), pp. 634-638.

38 Paris, Bibliothèque Nationale MS Lat $12849, \mathrm{f}^{\circ} 219 \mathrm{r}^{\circ}-221 \mathrm{r}^{\circ}$. 